\title{
A STUDY ON THE ADOPTION OF DIGITAL FINANCIAL SERVICES IN SERVICE SECTOR ORGANIZATIONS
}

\author{
Shailesh Ramratan Vaishnava \\ Research Scholar, Department of Commerce, Rabindranath Tagore University, \\ Madhya Pradesh, India \\ Dr. Deepti Maheshwari
}

Dean, Faculty of Commerce, Rabindranath Tagore University, Madhya Pradesh, India

\section{Dr. Sangeeta Jauhari}

Dean, Faculty of Humanities and Liberal Arts, Rabindranath Tagore University, Madhya Pradesh, India

\begin{abstract}
In the past, the word cash was commonly used in the city. A cashless economy is a trading platform; one does not have to deal with cash in a tangible way as an exchange, but instead uses credit or debit cards or a computer. It does not mean total withdrawal, but simply transforms the economy into a space that reduces the use of tangible money by providing alternative payment methods. The emerging economy and the emerging economy are making great strides in reducing paper spending. India holds the most complete product in the world, with papers costing Rs 21000 crores annually in RBI. In an effort to boost the economy and monitor taxpayers, the Indian government has launched its "moneyless India" campaign. To make India a safer society, the government has implemented various programs such as Digital, Digital Finance for Rural India, Visaka, Creating Awareness and Access through Community Service Centers (CSCs) and introduced many initiatives such as Unified Payments Interface, Unstructured I Supplementary Service Data (USSD) based on Mobile Banking, Aadhar payment system (AEPS), point of sale, National Electronic Funds Transfer (NEFT), Bharat Financial Interface (BHIM), Lucky GrahakYojana and Digi-VyaparYojana etc. included In this study, however, the main purpose of this study is to review the incomegenerating economy and its impact on the service sector especially Nagpur, Maharashtra while moving to a poorer society.
\end{abstract}

Key words: Payment system (AEPS), point of sale, National Electronic Funds Transfer 
Cite this Article: Shailesh Ramratan Vaishnava, Deepti Maheshwari and Sangeeta Jauhari, A Study on the Adoption of Digital Financial Services in Service Sector Organizations, International Journal of Management, 11(12), 2020, pp 3281-3290. http://iaeme.com/Home/issue/IJM?Volume=11\&Issue=12

\section{INTRODUCTION}

A cashless economy is an economy in which all forms of transactions are made through digital means. Includes e-banking (mobile banking or computers), bank and credit cards, swipe or identification cards (POS) and digital wallets. So the RBI government is making many efforts to reduce spending in the economy by promoting digital or payment devices that include prepaid tools and prepaid cards. RBI's efforts to promote these new forms of payment and accommodation are aimed at achieving the goal of a 'low-income' society. the most important assumption in the operation of such an economy is that it is a guarantee that people's money is safe in the banks. Also, travel without money is worth it, not only is it the first thing to value management, but it also brings a lot of images into the economic system. A moneyless economy helps to curb black people's money, suppresses the ruling tax and ultimately borrows money to finance illegal trade and counter-terrorism activities. As a result of this growing profit, many developing economies are using more savings and digital means. A low-income society is a popular way to deal with debt. The economics of trading without money do not mean a lack of money but reflect the culture of the people who process digital transactions. In today's financial world, money is flowing. Therefore, the spread of the digital payment culture alongside the expansion of infrastructure services is necessary to achieve the goal. The changes have created favorable market conditions for other digital payment methods, in addition to existing e-wallets and credit cards or credit cards. These are not just important bank apps or a website or. The Indian Payment Agency, along with the RBI, introduced the UPI ("UNITED PAYMENT INTERFACE"), which allows multiple accounts from participating banks, and provides multiple banking services in a single mobile system. Although India has an estimated 220million smartphone user since February 2016, there is still an increase thanks to up to 100\% of people with mobile internet access.

The government has made a huge change in the economic situation by making demons more expensive - Rs 500 and Rs 1000 from November 8, 2016 and headed to India for a money-free future. What is an economy without money? A financial crisis is when everything is done through electronic channels such as debit / credit card, cash Service (IMPS), National Electronic Funds Transfer (NEFT) and Real Time Gross Settlement (RTGS). The circulation of virtual currency is small. The Indian economy continues to be driven by less than $5 \%$ of all electricity payments. Electronic transactions want to drive the event and make India's modern payment system modern. The essence of the policy is to transform the economy from a financial economy to a non-financial economy. An efficient and modern payment system can greatly help to grow and improve driving. The policy also aims to improve the performance of fiscal policy, regulate inflation, and keep the system stable. In India, the median income of gross domestic product is $12.42 \%$ in GDP; this is often among the best in the world. It was $9.47 \%$ in China or 4 split with Brazil. In addition, the number of currency notes distributed was significantly higher than other major economies, India had 76.47 billion notes issued in 201213 compared to US \$ 34.5 billion.

The Indian payment system is rapidly moving to more IT-supported systems. within the retail sector we have the highest rates of financial transactions. in addition to cash, one of the growing payment methods used by merchants in the sector is payment cards. However, all the isometrics of the transition from a troubled economy to a financially troubled economy are somehow linked to demonic practices that aim to swindle money out of the system in order to 
earn money for black people. With the growing increase in electronic payments, especially those for e-commerce and m-commerce, there is a growing need for faster payment services, which makes it easier to conduct financial transactions. Reducing the reliance on the Indian economy for money appeals for a variety of reasons. India has one of the leading currencies to measure domestic commodity within the name, and to soften economic activity at the expense of paper. According to a 2014 study by Tufts University, the value of money in India, financial performance costs the Federal Reserve Bank of India (RBI) and commercial banks about Rs21,000crore per year. Also, moving away from money will make it harder for refugees to pay their bills, a major benefit to a country with a financial crisis.

India is a vigorous effort to understand the economics of foreign trade by reducing corporate consumption. Digital inclusion can be a process that can help the economy move towards a poorer society. The practice of money laundering and money laundering began in the mid1990 's, when electronic music became popular. As the 2010 digital payment system is being rolled out too many countries with examples including mediators such as PayPal, digital wallet schemes operated by companies such as apple, subcontractors and NFC payments electronically or by smart phone and bank and bank loans are widely used. In 2010 money was unpopular with some types of transactions that could historically be used to pay for tenderers and large numbers where in some cases they were treated suspiciously, due to their efficiency and ease of use in concealing and supporting terrorism and actively banned by other suppliers and traffickers. In 2016 within the UK it was reported to one in seven people who do not have or do not spend money. Our 2016 Consumer Survey found that $75 \%$ of respondents preferred debt or open debt as their payment method while only $11 \%$ of respondents prefer money. In 2017, digital payment methods such as Venmo and Square offer cash-strapped sales. Venmo allows each person to pay directly to another person without earning money. Square is a new feature that allows especially small businesses to receive payments from their customers.

\subsection{Financial Benefits Small Economy}

A small economy with a financial crisis helps to curb black money. As a result, it reduces land prices because more black people are invested in land that reduces the cost of world markets. 1 in 7 notes is intended to be counterfeit, with a negative impact on the economy, through money laundering, which will be avoided. The extensive use of digital payments in cash will allow for a more detailed record of all public events, allowing greater visibility in business operations and transfers that reduce leisure and coverage. The economy has no money and reduces the value of banking services. It also develops a fiscal policy to control inflation and boost economic growth in our country. Another good thing about a moneyless economy is that it does not encourage money laundering and other money-related cases.

\section{REVIEW OF LITERATURE}

AslamHasan, Mohammed AtifAman, Mohd Ashraf Ali (2020) conducted a course called "Cashless Economy in India: Challenges ahead". The purpose of this study was to look at the major challenges facing Indians in the way of earning money. To achieve the objectives of this type of personal study assessment, interviews were conducted. After the study was completed most of the people were concerned about security and privacy issues. Lack of infrastructure is also a challenge for two-thirds of the community. One of the challenges facing the Indians is the lack of education and economic knowledge.

CA Kiran N. Gajjar (2019) conducted a study entitled "STUDY OF CASHLESS ECONOMY OF INDIA". This paper focuses on an understanding of India's inflation plan and will highlight major barriers to inflation and electricity. Exploratory studies are conducted to calculate transaction costs borne by customers and banks on the way to a low-income 
community. After the study completed the economy without money without a grant program. It would be better to say that India at this time should visit a smaller financial economy than going into the economy. Ongoing march towards a small economy will soon create a cashstrapped economy in the country soon.

Rudresha C.E (2019) conducted a study on "Cashless Transaction in India: A Lesson". This paper focuses on ideas and ways to trade without money in India. In addition, the study looks at the benefits and limitations of a non-profit economy outside the community. After the study concluded that the foreign exchange economy is one of the best and strongest decisions in the Indian government. Most people accept the concept of a free trading system. It helps to fight big and illegal economic activities such as terrorism, corruption, money laundering etc.

Kousalya and Shankar (2018), conducted studies entitled "Cashless economy / transaction". This paper focuses on understanding the economic impact of finance and its importance in India. After research it has been shown that the introduction of a low-income economy in India will have a positive impact on the financial sector and could help to make the payment system more modern in India.

Dominic, Saranya, and Rajani (2018), have researched the transformation of individual economic behavior into a non-financial economy. The study aims to study individual behavioral changes in relation to a moneyless economy. After the study it was found that many people have migrated or gone to a poor country but there is still an extended way that India has no money.

Manpreet Kaur (2017) conducted studies on demon possession and the impact on the Free Payment System. He said a system without money in the economy has many advantages over time consuming fruits, low cost, small transaction paper etc. And you expect the full transaction to be a non-financial transaction.

K. Veerkumar (2017) stated in a study that demon possession had a very positive and immediate impact on the state of the Indian economy. In addition, the researcher has tried to find the impact of the state's drag on society. It turns out that demon control helps to get rid of black people's money that the first position given to respondents and then followed by corruption, terrorism etc.

Asra Fatima (2017) researched and explained that according to the RBI (Reserve Bank of India) Annual Report for April 2015 to March 2016, these two notes combined to make up $86.4 \%$ of the total amount in March 2016, were Indian rupees 16.42 trillion. With one stroke, the govt. excluded $86.4 \%$ of the total amount. In terms of volume, monetary notes in two volumes account for $24.4 \%$ of the 90.27 billion pieces. We continue to seek the effect of social empowerment, research concludes, however, that it is still a mistake to expect because it is the first step in a profitable financial society in the country. The step is govt. what is taken is a fact that will have a positive impact on the economy or the country not in a rapid way but will definitely support the Indian economy.

Pradeep H. Tawade (2017), conducted a study entitled "The future and scope of the financial economy in India." This paper helps to explore long-term trends and therefore the impact of money laundering within the Indian economy. After research it became clear that the government. Indians should look at many steps to make India digital. And payment methods should be made safer and less risky.The study represents Cashless Economy and its Impact on Service Sector which is primarily of descriptive and analytical research based on empirical pieces of evidence in the form of primary and secondary data. Though the study has not used any advanced quantitative methods, suitable statistical tools were used to make the data more precise and systematic. The enquiry is essentially qualitative. The study is based on the descriptive statistics where data is presented in averages, percentages, weighted mean score and chi-square method. 


\section{OBJECTIVE OF THE STUDY}

To study the adoption of digital financial services in service sector organizations of Nagpur.

\section{RESEARCH METHODOLOGY}

\subsection{Research Design}

The present study includes respondents which was select on the basis of probability sampling method from capital of Maharashtra state. The city was Nagpur. For the purpose of this extensive study of cashless economy and its impact on service sector has been taken. The study covers the total sample size of 700 from selected city of Maharashtra state The researcher selected city of Maharashtra, Nagpur. Maharashtra is the third largest state by area in India. Maharashtra (42.4\%) ranks 2nd in terms of urbanization in India as compared to all other States. The state is divided has 36 districts, 355 talukas, 535 cities, 63,663 villages, 6 administrative divisions with the capital being Nagpur. The city selected for the study in Maharashtra is based on probability sampling.A sample set of 700 respondents' presently taken for the purpose of the study.

\subsection{Sources of Data}

Every research is conceived and carried out with the support of relevant information known as data. So it is important to prematurely decide the sources from where the data is to be collected. The present research is conducted based on secondary as well as primary data which has been discussed below:

\subsubsection{Secondary Data}

Secondary sources of data were used and they include record files, brochures, dissertations, project reports, research papers, books, hand books, government reports, newspapers, websites etc.

\subsubsection{Primary Data}

The researcher personally visited the selected city of Maharashtra. An administered questionnaire was circulated the selected respondents' including the Customers, Industrialist, Businessman, Government employee, Private employee and others. Data was collected through the self-structured questionnaire, and their responses were collected.

\section{RESULTS}

Total 16 items present the factors related the facilitation of cashless economy whose 888reliability value is .88 . So, it can be inferred from the value that $88.8 \%$ scale is reliable so it is better to carry further analysis.

Table 1 Reliability Statistics

\begin{tabular}{|c|c|}
\hline Cronbach's Alpha & N of Items \\
\hline .888 & 16 \\
\hline
\end{tabular}

$\mathrm{H}_{01}$ : There is no significant difference among the service sector organizations towards the adoption of digital financial services.

One Way ANOVA of adoption of cashless transaction system across the respondents of different service sectors. ANOVA is carried out to compare means of all the service sector organizations for a cashless transaction system to determine whether there is significant difference in these mean across respondents of different service sectors using the F distribution. 
The information about ANOVA across different service sectors categories of employees is presented in the table:

Table 2 Descriptives on Service Sector Organizations towards the Adoption of Technology

\begin{tabular}{|c|c|c|c|c|c|c|c|c|}
\hline & \multirow[t]{2}{*}{$\mathbf{N}$} & \multirow[t]{2}{*}{ Mean } & \multirow[t]{2}{*}{$\begin{array}{c}\text { Std. } \\
\text { Deviation }\end{array}$} & \multirow[t]{2}{*}{$\begin{array}{l}\text { Std. } \\
\text { Error }\end{array}$} & \multicolumn{2}{|c|}{$\begin{array}{l}\text { 95\% Confidence } \\
\text { Interval for Mean }\end{array}$} & \multicolumn{2}{|c|}{ Minimum|Maximum } \\
\hline & & & & & $\begin{array}{l}\text { Lower } \\
\text { Bound }\end{array}$ & $\begin{array}{l}\text { Upper } \\
\text { Bound }\end{array}$ & & \\
\hline IT Park & 35 & 13.0286 & 3.05331 & .51610 & 11.9797 & 14.0774 & 8.00 & 20.00 \\
\hline Tourism & 35 & 13.9714 & 3.35617 & .56730 & 12.8185 & 15.1243 & 7.00 & 20.00 \\
\hline Hotels & 35 & 14.5429 & 3.38980 & .57298 & 13.3784 & 15.7073 & 5.00 & 20.00 \\
\hline Banking & 35 & 14.7714 & 4.38638 & .74143 & 13.2647 & 16.2782 & 6.00 & 20.00 \\
\hline $\begin{array}{c}\text { Education Training } \\
\text { Services }\end{array}$ & 35 & 14.2571 & 4.44140 & .75073 & 12.7315 & 15.7828 & 6.00 & 20.00 \\
\hline $\begin{array}{l}\text { Government } \\
\text { Agencies }\end{array}$ & 35 & 12.9143 & 4.06832 & .68767 & 11.5168 & 14.3118 & 6.00 & 20.00 \\
\hline Metro Services & 35 & 14.8000 & 2.02630 & .34251 & 14.1039 & 15.4961 & 10.00 & 19.00 \\
\hline $\begin{array}{c}\text { Infosys, TCS (Tata } \\
\text { Consultancy } \\
\text { Services) }\end{array}$ & 35 & 14.6571 & 2.08556 & .35252 & 13.9407 & 15.3736 & 8.00 & 17.00 \\
\hline Transportation & 35 & 14.8571 & 2.76685 & .46768 & 13.9067 & 15.8076 & 7.00 & 20.00 \\
\hline $\begin{array}{l}\text { Oil and Gas } \\
\text { Services }\end{array}$ & 35 & 16.0000 & 2.77595 & .46922 & 15.0464 & 16.9536 & 10.00 & 20.00 \\
\hline $\begin{array}{l}\text { Architectural \& } \\
\text { Engineering } \\
\text { Services }\end{array}$ & 35 & 15.6857 & 2.47067 & .41762 & 14.8370 & 16.5344 & 11.00 & 20.00 \\
\hline Hospitals & 35 & 14.1143 & 3.34111 & .56475 & 12.9666 & 15.2620 & 8.00 & 20.00 \\
\hline Airlines & 35 & 13.9714 & 3.61765 & .61149 & 12.7287 & 15.2141 & 7.00 & 20.00 \\
\hline $\begin{array}{c}\text { Telecommunication } \\
\text { Services }\end{array}$ & 35 & 13.9429 & 3.09594 & .52331 & 12.8794 & 15.0064 & 5.00 & 20.00 \\
\hline $\begin{array}{c}\text { Insurance Operator } \\
\text { Services }\end{array}$ & 35 & 15.7429 & 2.77958 & .46983 & 14.7880 & 16.6977 & 10.00 & 20.00 \\
\hline \begin{tabular}{|c|} 
Financial \\
Transaction \\
Processing \\
\end{tabular} & 35 & 14.4857 & 3.91356 & .66151 & 13.1414 & 15.8301 & 6.00 & 20.00 \\
\hline Shipping services & 35 & 13.2000 & 3.47935 & .58812 & 12.0048 & 14.3952 & 7.00 & 20.00 \\
\hline $\begin{array}{c}\text { Computer Hardware } \\
\text { \& Software }\end{array}$ & 35 & 13.1429 & 4.33279 & .73238 & 11.6545 & 14.6312 & 5.00 & 20.00 \\
\hline Real Estate & 35 & 15.5429 & 4.56549 & .77171 & 13.9746 & 17.1112 & 8.00 & 20.00 \\
\hline $\begin{array}{l}\text { CSC (Common } \\
\text { Service Centres) }\end{array}$ & 35 & 1 & 5.98500 & 5 & 2 & 1 & 0 & 0 \\
\hline Total & 700 & 14.3343 & 3.68964 & .13946 & 14.0605 & 14.6081 & 4.00 & 20.00 \\
\hline
\end{tabular}

The table on the mean difference among various service sector organizations towards the adoption of technology. It shows that the highest mean for oil and gas services is observed so it means that in this organization, all the operations depend upon the cashless economy that facilitates the transparency and integrity. It helps the employees in executing their work with full efficiency and devotion. Hence, in this organization, no financial error is noticed. Then the second highest mean for Insurance operator services where investors go for online transactions as on the website, they are supposed to pay online. Then comes to the architectural engineering where the cashless transactions have its own importance. Apart from other service sectors also, cashless economy is growing accordingly the preferences of society. Every service organization owns their websites and formulate all the things online for providing convenient to their customers. The cashless economy has expanded the business and able to generate a number of opportunities. 


\section{ANOVA on Service Sector Organizations towards the Adoption of Technology}

\begin{tabular}{|l|l|l|l|l|l|}
\hline & $\begin{array}{l}\text { Sum of df } \\
\text { Squares }\end{array}$ & $\begin{array}{l}\text { Mean } \\
\text { Square }\end{array}$ & F & Sig. \\
\hline $\begin{array}{l}\text { Between } \\
\text { Groups } \\
\text { Within } \\
\text { Groups } \\
\text { Total }\end{array}$ & 609.949 & 19 & 32.103 & 2.451 & .001 \\
\hline
\end{tabular}

Figure 1

To test the association between service sector organizations and the adoption of digital financial services, ANOVA is applied and found that the value of analysis of variance is 2.451 (higher than tabulated value) which is not significant at degree of freedom $=19$ and $p$ value .001 is lower than 0.05 so the null hypothesis 'There is no significant difference among the service sector organizations towards the adoption of digital financial services' is rejected. It is concluded that among all the service sector organizations perceived in different manner for the adoption of digital financial services.

\section{CONCLUSION}

For the study, respondents were chosen from service sectors in Nagpur city with diverse backgrounds. It included many service organizations who have a speedy rate of transacting in cashless such as; IT, Tourism, Hospitality, Educational services, Financial services, banking, insurance, airlines, telecommunication services, metro services, common services, shipping services, hospitals, transportation, Government agencies, real estate, computer hardware and software industries, etc. Regarding the gender of respondents, $59.4 \%$ were male respondents and rest $40.6 \%$ were female respondents. It is revealed that both male and female are familiar with the digitalization as they are from various service industries like IT, Tourism, Hospitality, Educational services, Financial services, banking, insurance, airlines, telecommunication services, metro services, common services, shipping services, hospitals, transportation, Government agencies, real estate, computer hardware and software industries, etc. It is found that these industries have created its own space employees from these service sectors are required to follow the digital economy to make profits. Among them, the majority of respondents were between 26 to 35 years as the young generation engaged in cashless transactions because they are very familiar with technology. Then the next segment of age group was between 36 to 45 years. The least percentage was of those respondents who were 46 to 55 years. Hence, age is important parameter in accessing the online transactions.

The findings disclosed that income is an important factor in considering the frequency of cashless transaction so in this study it is found that those respondents who have more than 80,000 income segment monthly, they have more frequency in accessibility of cashless transactions. This income segment is followed by those respondents who have different earnings. Respondents do cashless transactions as per their convenient and requirements. People do not worry about cash which were carried out before digitalization so it is easy for all the segment of people. The ability to use digital technology, communication tools or networks to locate, evaluate, use and create information depends upon the consumer literacy which he 
get from different sources like Banking Staff/Agents, Advertisement, Family members, Friends/colleagues. The ability to understand and use information in multiple formats from a wide range of sources when it is presented. Moreover, it is not feasible to force illiterate people to use debit and credit cards in the name of cashless transactions as the banking system in India is still unsecured and many fraudulent practices like online money thefts continue to occur. Many literate people also don't know how to operate cards and do transaction digitally.

The result indicated that possible in all the service sector, employees are engaged in online transactions means involvement in cashless economy. Hence, to look the perspective of service sector employees total 20 service organizations. These findings confirm previous studies by Michaels (2011) that speed of payment and fewer complexity increases influence adoption of electronic payment. Also support Kenneth (2012) that convenience is a factor that determines adoption of electronic payment in small and medium businesses. Further the finding is consisted with Mas (2013) that low storage is critical to electronic mode of payments. Online to Offline market is increasing right now, as there are many financial company starts to realize that no matter what happened, there are definitely would be some people who prefer cash to anything. The usage of internet always increase every year, so no wonder online shopping would double too. However, not many people are comfortable to give their details easily to someone that they do not know. There are various reasons for users to prefer cashless economy as fear of theft, lack of trust, wear and tear of money, maintain record, etc.

\section{SUGGESTIONS}

On the basis of results some suggestions have been given for improvements in the transformation of cashless economy:

People should be properly trained. People should be taught how to use cards in ATMs so that they can use them without difficulty.In order to carry this facility to rural and remote India, proper infrastructure must be built in remote areas. People should be trained so that they can make the most of their money by using cashless methods. The advantages of cashless transactions should be communicated to both buyers and sellers.

It would thus be able to be reasoned that with the expanding notoriety of exchanges through cards, money is gradually expected to kick the bucket a characteristic demise. From the investigation over, the exploration found that the appropriation of the credit only framework diminishes the danger related with paper cash. One of the most important promises of the credit-only system is that it is used to reduce the risk of money transmission. Individuals will have less need to transfer money around now that most transactions are settled electronically, and as a result, money loss, burglary, and robbery will all decrease. There is a need to teach them about the separating components of the Cashless Transaction System. It is true, there are troubles in executing the possibility of credit only economy in an immense nation like India where countless individuals are living under hopelessness and neediness, yet a start must be made sometime in the future. Today, there is an ocean change in the outlook of individuals concerning computerized methods for money related dealings which are protected, simple, advantageous and straightforward. Smooth, straightforward and secure cycles will assist with achieving conduct changes and quicker appropriation of computerized and banking among unbanked portions. At the point when new players enter the market, each with a somewhat extraordinary interpretation of the market and with contrasting plans of action, the expanded rivalry will help the climate and offer more choices for buyers to look over. 


\section{REFERENCES}

[1] Akhalumeh PB, Ohiokha F (2012) Nigeria's Cashless Economy: The Imperatives. IJMBS 2(2): 33.

[2] Agwu, E. (2012). A Qualitative Study of the Problems and Prospects of Online Banking in Developing Economies - Case of Nigeria, Journal of Internet Banking and Commerce, 17(3):120.

[3] Anthonima K. Robin. et.al, India Moving towards Cashless Society. International Journal of Engineering \& Scientific Research (IJMRA Publications) Vol. 6 Issue 5 May 2018.

[4] Ashish Das, and Rakhi Agarwal, Cashless Payment System in India- A Roadmap, Technical Report 2010. http://dspace.library.iitb.ac.in/jspui/handle/10054/1732.

[5] Bansi Patel, UrviAminPlastic Money, RoadmayTowards Cash Less Society Paripex - Indian Journal of research Volume 1, Issue 11, November 2012.

[6] Banknet India, (2008)., Bank Customer Survey Research Report on Payment Systems was released at Fourth International Conference on Payment Systems held on January 16, at Mumbai. Taj Lands' End http://www.banknetindia.com/books/pssurvey.html.

[7] Balakrishnan. M (2007) "Working capital management - Impact of emerging electronic payment Options in India." The Indian Banker, vol.2 (.6) pp.18-26.

[8] Chijindu VC, Inyiama HC (2012). Social implication of robots - An overview, International Journal of Physical Sciences, 7(8): 1270-1275.

[9] Dahunsi FM, Akinyede RO (2014). ICT Perspectives on the Feasibility Analysis of the Cashless Economy in Nigeria, African Journal of Computing \& ICT, 7(5): 45.

[10] DeepikaKumari, Cashless Transaction: Methods, Applications and Challenges, International Journal of Enhanced Research in Educational Development (IJERED) Vol. 4 Issue 6, Nov-Dec, 2016.

[11] Ejoh NO, Adebisi AW, Okpa IB (2014). Information and Communication Technology - An Indispensable Tool for the Implementation of Cash-Less Policy in Nigeria, International Journal of Economics, Commerce and Management, 2(10): 5.

[12] Irefin IA, Abdul-Azeez IA, Tijani AA (2012). An Investigative Study of the Factors Affecting the Adoption of Information and Communication Technology in Small and Medium Scale Enterprises in Nigeria, Australian Journal of Business and Management Research, 2(2):1-9.

[13] National Commission For Mass Literacy (NCML. 2010). The National Literacy Survey, Adult and Non Formal Education, Media \& Marketing Communications Company Group Nigeria: National Bureau of Statistics. Retrieved on 14.04.2016 from: www.nigerianstat.gov.ng.

[14] Odior ES, Banuso FB (2013). Cashless Banking in Nigeria: Challenges, Benefits and Policy Implications, European Scientific Journal, 8(12): 289-316.

[15] Okey OO (2012). The Central Bank of Nigeria's cashless policy in Nigeria: Benefits and challenges, Journal of Economics and Sustainable Development, 3(14): 128-133. 
[16] Oluwatobi SO, Ogunrinola IO (2011). Government Expenditure on Human Capital Development: Implications for Economic Growth in Nigeria, Journal of Sustainable Development. 4(3):72-90.

[17] Pradeep H. Tawade, "Future and Scope of Cashless Economy in India”. IJARIIE, Vol-2 Issue3 2017.

[18] Pranjali A. Shendge, et.al, Impact and Importance of Cashless Transaction in India, International Journal of Current Trends in Engineering \& Research (IJCTER) Volume 3 Issue 4, April 2017 PP. $22-28$.

[19] PreetiGarg, et.al, Study on Introduction of Cashless Economy in India 2016: Benefits \& Challenge's, IOSR Journal of Business and Management (IOSR-JBM). Volume 19, Issue 4. Ver. II (Apr. 2017), PP 116-120.

[20] Sheetal Thomas, et.al, Cashless Rural Economy - A Dream or Reality? Jharkhand Journal Of Development and Management Studies, XISS, Ranchi, Vol. 15, No.2, June 2017, PP. 72697281

[21] Srinivas, N. (2006). An Analysis of the Defaults in Credit Card Payments, Southern Economics. July. pp. $19-21$.

[22] TusharChaudhari, The Critical Analysis of Cashless Transaction. International Journal of Commerce and Management Research, Volume 3; Issue 3; March 2017; Page No. 92-94.

[23] V. Kokila et.al, A Study on Consumer Behavior on Cashless Transaction in U.T of Puducherry, KAAV International Journal of Economics, Commerce \& Business Management KIJECBM/Apr-June (2017)/Vol-4/Iss-2/A29 Page No.207-216. 